\title{
The Implementation Of Contextual Teaching And Learning (CTL) Improving Social Skill And Cognitive Development Of Kindergarten Children Group B
}

\author{
Muznah. Siti Masitoh, Rachma Hasibuan \\ Universitas Negeri Surabaya \\ Surabaya, Indonesia \\ Muznah@saim.sch.id
}

\begin{abstract}
The large number of learning applications focused on transferring knowledge, repetition, and non-contextual teaching in pre-school becomes the background of the study. The objectives of the research are 1) to know the influence of Contextual Teaching and Learning (CTL) in improving cognitive development and social skill of early childhood (2) to prove the application of CTL learning that can change the mindset of early childhood teachers into methods that can be applied in the learning process. The research stands on constructivism theories because CTL is the learning that is based on situated cognition. The method of the research is quantitative experimental. The population of the research is 260 students TK-B cluster V Sukolilo district, Surabaya. The samples of the study are 36 students as an experimental group and 36 students as a control group which was selected randomly. The researchers compared the results of cognitive development that used CTL and without CTL. Data analysis used SPSS 17 program for windows evaluation version. The results showed that SPSS 17 proved the significant influence of cognitive development and social skill of TK-B cluster V Sukolilo district after applying CTL method.
\end{abstract}

Keywords-Contextual Teaching and Learning, cognitive, social skills

\section{INTRODUCTION}

PAUD or Early Childhood Education, is a fundamental education vehicle in the process of growth and development also character building for children. It is important for a teacher to educate and guide the children in order to develop it, so that the child's potency will be optimized. Early childhood education process should be done with the intention of giving the basic concepts that have meaning for the children. Social skill is the principal component in early childhood development. Social skill is a predictor that greatly affects the academic achievement of children compared to cognitive skill [1]. Social skill is the foundation of social adjustment that is necessary for life.
Without adequate social skills, children will get issues in friendship and even not maximal academic achievement [2]; [3]; [4]. Another research has also shown that children who do not have good social skills will experience difficulty through transition phases at every level [5]. One of the things that contribute to the problem of social development of children is the approaches and methods applied in education in kindergarten. According to Miller and Almon [6], the practice of learning in America shows that kindergarten children get more instruction and tests in reading and counting than get learning through games, exploration, physical activity and imagination. Many teachers use a prescriptive curriculum directed to prepare children in standardized tests that do not pay attention to the child's mental development. Likewise PAUD teachers in Indonesia are also less creative in developing learning methods (Anjani, 2015). These two things contribute to the increased frustration, stress and anger in children and sometimes even an impact on extreme behavioral problems [6]. The report of The National Scientific Council on the Developing Child (2005)[7] states that stress at an early age causes damage to the ability of reasoning and critical thinking, IQ. Therefore, assessment and change of teacher mindset needed to be able to carry out learning activities that facilitate children's social and cognitive development, so that children feel unencumbered (fun) in the learning process. Piaget argues (as cited in Mutiah, 2010: 101) that the child creates his own knowledge of his world through interaction with his environment, practices using previously heard information and incorporates new information with familiar skills. Children also test their experiences with new ideas. So, it is substantial to develop the child's cognitive skill in the right way. It aims to enable the children to develop the perception based on what they see, hear, and perceive. So that the children will have comprehensive understanding and they can train their memory of all the 
events they have experienced so that children are able to develop their ideas in order to connect an event with other events; so that children understand the various symbols scattered around it; so that children are able to make good reasoning that occurs in a natural process (spontaneous) or through a scientific process (experiment). One of the alternative learning that can meet the learning criteria for real children is learning Contextual Teaching and Learning (CTL).

Contextual Teaching and Learning (CTL) is a learning based on research situated cognition [8] who found that constructive learning processes such as critical thinking, inquiry, and problem solving should be placed in the physical, intellectual and socially appropriate [9]; [10].

This learning motivates children to link their knowledge and the application in everyday life [11]. Johnson (2002) adds that CTL allows children to connect the content of academic learning to the context of everyday life to find meaning. CTL also broadens the child's personal context through new experiences that stimulate the brain to create new relationships so that they can discover new meanings.

Based on the background, this research is entitled as "The Implementation of Contextual Teaching and Learning Model in Improving Social and Cognitive Skill of Kindergarten Children Group B”.

The problem of this research is "Does the Contextual Teaching and Learning Model Improve Social and Cognitive Skill of Kindergarten Children Group B?"

This research is aimed to improve the social and cognitive skill of kindergarten children by applying contextual teaching and learning model.

\section{METHOD}

The research approach used is quantitative research with experimental research model. The subjects of this research are students of Group B TK Sekolah Alam Insan Mulia Surabaya and TK Hangtuah XVIII Surabaya, Sukolilo District. This location is selected based on the technique of "random sampling". The samples of this research are 36 children in the control class and 36 children of the experimental class. Data collection is done by observation and documentation.

Data analysis technique in quantitative research uses statistics, both descriptive statistics and inferential statistics. Prior to the analysis, it is first tested the requirements analysis of the normality test and homogeneity test between variants. The prerequisite analysis test by using the computer program SPSS 17 for windows evaluation Version.

\section{RESULT AND DISCUSSION}

Johnson (2002)[12] said, "Contextual teaching and learning enable students to connect the content of academic subjects with the immediate context of their daily to discover meaning". This means that contextual learning allows the child to relate the content of the material to the context of everyday life in finding meaning. So, it can be said that contextual learning is a learning that connects between the material that is learned with the children's everyday real life, whether in the family environment, school, community or citizen with the purpose of finding the meaning of the material in their life. CTL is based on the philosophy of constructivism. Constructivism is one of the philosophies of knowledge emphasizing that knowledge is its own construct (Glasersfeld, 1989).

Contextual Teaching and Learning (CTL) is a learning based on research situated cognition [8]; [13] who found that constructive learning processes such as critical thinking, inquiry, and problem solving should be placed in the physical, intellectual and socially appropriate [9]; [10]. In the realization, it should pay attention to 8 components, namely: 1) making meaningful relationship between subjects of learning with daily life, 2) doing meaningful exercises, 3) independent learning, 4) collaboration, 5) creative and critical thinking, 6) attention to the individual, 7) achievement of high standards and 8) using the test for authentic assessment.

Bikos and Gregiriadis (in Gregoriadis, 2013:40) said that developing positive social skills can help young children make friends and succeed in school. Meanwhile, social development according to Harlock (1978:250) is a child's ability to build the social relationship or socialize, namely social behave according to social demands in the environment. Social development of early childhood is the development of skill in a child's life including empathy, communication, cooperate and also the intrapersonal process used to behave according to the norm of an environment around. Children who have good social development will be easily accepted by the environment around their life in the future. According to Piaget (in Thobrani and Mustafa, 2011; 93) the theory of cognitive developmental learning is a theory that views cognitive development as a process where children actively build systems of meaning and understanding of reality through experiences and interactions that occur. The learning process takes place based on a particular stage of development according to the characteristics of the child. According to Piaget (2014), a child progresses through four stages of cognitive development, from birth to adulthood, which is sensorimotor, preoperational, concrete, and formal operations. In conducting learning activities of early childhood cognitive development, teachers should pay 
attention and adjust to the stages of early childhood development. So that early childhood cognitive development can develop optimally. In this research, development of cognitive is investigated, including: 1) Learning and Problem Solving (Knowing the concept of many and little, creating something according to child's own ideas related to various problem solving), observing objects and symptoms with curiosity. 2) Logical thinking (classifies objects by function, shape or color or size, classifies objects into the same group). 3) Symbolic Thinking (counting many things one to ten, recognizing the concept of numbers, recognizing the symbol of numbers).

\section{CONCLUSIONS}

Based on the results of the theories review and research in the field, there is an increase of social and cognitive skills of children who received treatment with Contextual Teaching and Learning (experimental group) when compared before getting the treatment. The application of CTL in early childhood includes activities that contain elements: experiencing, applying, cooperating, and transferring. The four activities are in one unity that can not be separated from each other and can improve the skill of early childhood.

\section{REFERENCES}

[1] C. C. Raver and J. Kintzer, "What research tells policy makers about strategies to promote social and emotional school readiness among three and four year olds," Washington, DC Natl. Cent. Child. Poverty. Retrieved May, vol. 30, p. 2013, 2002.
[2] K. L. Lane, C. C. Givner, and M. R. Pierson, "Teacher expectations of student behavior: Social skills necessary for success in elementary school classrooms," J. Spec. Educ., vol. 38, no. 2, pp. 104-110, 2004.

[3] B. Johns, E. Crowley, and E. Guetzloe, "The central role of teaching social skills: focus on exeptional children," in Sociological Forum, 2005 , vol. 37 , no. 5 , pp. $7-14$.

[4] M. E. Logue, "Early childhood learning standards: Tools for promoting social and academic success in kindergarten," Child. Sch. vol. 29, no. 1, pp. 35-43, 2007.

[5] L. R. Betts and K. J. Rotenberg, "Trustworthiness, friendships, and self-control: factors that contribute to young children's school adjustment," Infant Child Dev. An Int. J. Res. Pract., vol. 16, no. 5, pp. 491-508, 2007.

[6] E. Miller and J. Almon, "Crisis in the kindergarten: Why children need to play in school.," Alliance Child., 2009.

[7] N. S. C. on the D. Child, "Excessive Stress Disrupts the Architecture of the Developing Brain (Working paper 3)." The Centre on the Developing Child at Harvard University, 2005.

[8] P. Cobb and J. Bowers, "Cognitive and situated learning perspectives in theory and practice," Educ. Res., vol. 28, no. 2, pp. 4-15, 1999.

[9] F. Brown, "The effect of an inquiry-oriented environmental science course on preservice elementary teachers' attitudes about science," $J$. Elem. Sci. Educ., vol. 12, no. 2, p. 1, 2000.

[10] A. M. L. Cavallo, R. B. Miller, and G. Saunders, "Motivation and affect toward learning science among preservice elementary school teachers: Implications for classroom teaching," J. Elem. Sci. Educ., pp. 25-38, 2002.

[11] S. J. Sears, Introduction to contextual teaching and learning. Phi Delta Kappa Educational Foundation, 2003.

[12] E. B. Johnson, Contextual teaching and learning: What it is and why it's here to stay. Corwin Press, 2002.

[13] D. Kumar and J. F. Voldrich, "Situated cognition in second grade science: Literature books for authentic contexts," J. Elem. Sci. Educ., vol. 6 , no. 2, p. 1, 1994 